\title{
Admission of Foreign Citizens to the General Teaching Hospital of Bologna, Northeastern Italy. An Epidemiological and Clinical Survey
}

\author{
Sergio Sabbatani ${ }^{1}$, Elena Baldi ${ }^{2}$, \\ Roberto Manfredi ${ }^{1}$ and Francesco Chiodo ${ }^{1}$
}

\author{
${ }^{1}$ Department of Clinical and Experimental Medicine, Infectious \\ Diseases Section, ${ }^{2}$ Department of Health and Public Care, University \\ of Bologna; “Alma Mater Studiorum”, Azienda Ospedaliera di \\ Bologna, Policlinico S. Orsola-Malpighi, Bologna, Italy
}

Background. The emergency regarding recent immigration waves into Italy makes continued healthcare monitoring of these populations necessary. Methods. Through a survey of hospital admissions carried out during the last five years at the S. Orsola-Malpighi General Hospital of Bologna (Italy), all causes of admission of these subjects were evaluated, together with their correlates. Subsequently, we focused on admissions due to infectious diseases. All available data regarding foreign citizens admitted as inpatients or in Day-Hospital settings of our teaching hospital from January 1, 1999, to March 31, 2004, were assessed. Diagnosis-related group (DRG) features, and single discharge diagnoses, were also evaluated, and a further assessment of infectious diseases was subsequently made. Results. Within a comprehensive pool of 339,051 hospitalized patients, foreign citizen discharges numbered 7,312 (2.15\%), including 2,542 males $(34.8 \%)$ and 4,769 females $(65.2 \%)$. Males had a mean age of $36.8 \pm 14.7$ years, while females were aged $30.8 \pm 12.2$ years. In the assessment of the areas of origin, $34.6 \%$ of hospitalizations were attributed to patients coming from Eastern Europe, $\mathbf{1 5 . 3 \%}$ from Northern Africa, $7.3 \%$ (comprehensively) from Western Europe and United States, 6.9\% from the Indian subcontinent, 5.9\% from sub-Saharan Africa, 5.7\% from Latin America, 4.1\% from China, $2.5 \%$ from the Philippines, and $1.1 \%$ from the Middle East. Among women, most hospitalizations $(\mathbf{5 8 . 8 \%})$ were due to obstetrical-gynecological procedures or diseases, including assistance with delivery $(\mathbf{2 7 . 1 \%})$, and pregnancy complications $(\mathbf{1 8 . 7 \%})$, followed by psycho-social disturbances $(5.9 \%)$, malignancies $(5.1 \%)$, gastrointestinal diseases $(4.7 \%)$, and voluntary pregnancy interruption (4.4\%). Among men, the most frequent causes of admissions were related to trauma $(15.9 \%)$, followed by gastroenteric disorders $(12 \%)$, heart-vascular diseases $(8.9 \%)$, psycho-social disorders $(8.4 \%)$, respiratory $(7.1 \%)$, kidney $(6.1 \%)$, liver $(5.2 \%)$, and metabolic $(4.9 \%)$ diseases, and

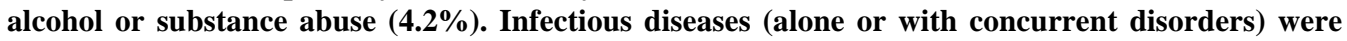
reported in 881 discharged individuals, representing $12.1 \%$ of the 7,312 DRGs attributed to foreign patients. The comprehensive patient population discharged from our hospital with at least one infectious disease diagnosis had lower rates of respiratory tract infections, followed by chronic viral hepatitis, HIV infection and related diseases, enterocolitis, pulmonary tuberculosis, pyelonephritis, severe skin and soft tissue infection, meningoencephalitis, and malaria, as the most frequentlyreported disorders. Conclusions. Our survey, through a combined analysis of both DRGs and discharge diagnoses, allowed us to conclude that $\mathbf{1 2 . 1 \%}$ of foreign citizens hospitalized at our General teaching Hospital of Bologna (Italy) suffered from at least one infectious disease. Respiratory tract, liver, and gastrointestinal infections, and HIV infection, were found with an appreciable frequency among discharge diagnoses, while the frequency of malaria and meningoencephalitis was lower, compared with other series. Among disorders other than infectious diseases, obstetric-gynecological conditions and post-traumatic episodes (for male patients) were the most frequent causes of hospitalization. Key Words: Foreign citizens, hospitalization, immigration, demographic and epidemiological features, clinical diagnoses, infectious diseases, outcome.

Italy is historically a country characterized by a mass emigration flow, which continued until the late fifties. Beginning in the mid-eighties, an absolutely novel immigration phenomenon has occurred in our country, which during the

Received on 10 November 2005; revised 17 March 2006.

Address for correspondence: Prof. Roberto Manfredi. Malattie Infettive, Policlinico S.Orsola-Malpighi. Via Massarenti, 11 - I-40138 Bologna (Italy). Telephone: +39-051-6363355. Phone/Fax: +39-051343500. E-mail: Roberto.manfredi@unibo.it

The Brazilian Journal of Infectious Diseases 2006;10(2):66-77. (C) 2006 by The Brazilian Journal of Infectious Diseases and Contexto Publishing. All rights reserved. subsequent years substantially affected the entire social context. A broad spectrum of cultural, social, economical, and health care modifications have occurred recently, after extensive immigration waves into our country, which found our institutions somewhat untrained to bear all the consequences, related to the unexpected extent of this immigration phenomenon, which brought to Italy an estimated three million people, with around 400,000 of them remaining in an illegal status [1].

It is usually supposed most immigrants have no relevant health problems upon leaving their country of origin [2]. Although at the time of departure there are usually no physical disturbances, these subjects probably have been 
exposed to diseases (of infectious origin, or not), which could have had some consequences (i.e. primary tuberculosis, "chronic" malaria, intestinal parasite infections). These health concerns are strongly correlated with the area of origin, so that a broad and varied spectrum of variables should be carefully considered, when considering both the migration phenomenon, and the individual foreign citizen. In our opinion, we cannot identify a specific "migrant type", remaining the same from a health care, social, economic, and anthropologic point of view. Several different features are typical of each immigrant, and they are generally consistent with the area of origin (i.e. the Balkans, Latin America, the Far East, and different regions of the African continent), and with the former socialeconomical position occupied by each migrant in his/her country of origin. Other differences emerge after the immigration process, and they are strictly related to the life and working project to be carried out in Italy (i.e. joining local communities of former immigrants, search for regular work, versus clandestinity and illicit activities).

These concepts need to be further examined, overcoming the limited, schematic and stereotyped perspective of "the immigrant" to a Western country, taking into account that profound differences may be present among these individuals, in the field of climate and environment, dietary attitudes, local endemic diseases, former cultural, political, socio-economic, and religious status, and prior and present health care resources. As a consequence, a "standardization" of all social-medical approaches is inadmissible and probably impossible to be performed. Though the availability of a "thousand keys" for a "thousand different doors" cannot be hypothesized in daily practice, immigrants also need to be seen in the perspective of specific anthropological features, which may give us the opportunity to appreciate the differences and the peculiarities of the ethnic communities that are becoming established in our country.

Infectious diseases, initially thought to be a potential, prominent problem in these immigrant populations, actually have relatively low prevalences, when compared with overall morbidity in the population and its very broad spectrum. According to a 2004 Italian survey [2] regarding infectious diseases that led to the hospitalization of immigrants, HIV infection ranked first, with $17 \%$ of cases, followed by tuberculosis (12\%), viral hepatitis (12\%), and malaria (4\%). As a whole, infectious diseases accounted for less than $10 \%$ of overall disorders that led the subjects to hospital admission [2].

In a general perspective, we decided to make a comprehensive assessment of all diseases involving hospitalization of foreign patients during the last five years, including both infectious and the far more frequent noninfectious illnesses. In a holistic perspective, the "patient" in his/her specific group (and not each single disease), should be the key focus of health care and social interest in this field.

\section{Material and Method}

Demographic background, patients, and objectives. The province of Bologna (North-Eastern Italy) at the end of 2002 had an overall population of 927,820 registered people, with 373,592 inhabitants in the metropolitan area of Bologna. Foreign citizens officially resident in Bologna and the province were 39,186 (4.2\% of the whole population), with people coming from Northern Africa as the most numerous community (31.5\%), followed by Eastern Europe (22\%), the Far East (12.9\%), the Indian subcontinent (11.3\%), sub-Saharan Africa (7.4\%), Latin America (4.6\%), and the Middle East (2.1\%). Foreigners coming from developed countries represented a cumulative $8.2 \%$ of cases. The first 15 national communities of foreign citizens living in Bologna and Province at the end of 2002 are reported in Table 1 [3].

In the year 1993, foreign citizens who lived in Bologna represented only $1.6 \%$ of the total population, but 10 years later (2002) this rate rose to $4.8 \%$. On the other hand, in the Bologna province, foreigners passed from $1.1 \%$ to $3.9 \%$ during the same time period [3].

In the year 2003, when considering separately persons coming from developing countries compared with the general population (autochtonous citizens, plus people coming from advanced areas of the world), the percentage was $5.2 \%$ in metropolitan Bologna, and $4.7 \%$ in the rest of Bologna province.

In the Bologna metropolitan area, over $75 \%$ of foreign citizens are aged 40 years or less; while in the overall population, this age group accounts for $39.4 \%$. In fact, the mean age of Bologna residents is around 47 years (five years more for females versus males), while foreigners are aged around 30 years on average, with absence of significant gender differences. Underage subjects (children and young people less than 18 years old) represent the $20.8 \%$ of foreign residents in the Bologna town area, while their frequency rises to $27.1 \%$ in the rest of Bologna Province (Figure 1).

Motivated by these evolving demographic data, a comprehensive survey on hospitalizations was carried out in the most important teaching Hospital of Bologna (S. OrsolaMalpighi Hospital, an 1,800-bed facility), in order to indirectly assess the prominent health problems of immigrants, by looking at admissions and their multiple correlates. The frequency of hospitalization of foreign citizens in the different age groups, also analyzed by gender, is shown in Figure 2.

The objectives of our study were: evaluation of the data on hospitalization of foreign citizens according to their demographic and epidemiological features, country of origin, and clinical diagnoses, with data analyzed separately for adult males, adult females, and children (aged $\geq 14$ years). The diagnosis at discharge, the duration of hospitalization, and the mode and time of discharge, were analyzed according to a broad spectrum of variables. Finally, particular attention was devoted to infectious diseases, establishing eventual links with associated 
Table 1. The most relevant and represented foreign communities living in Bologna, Italy, on December 31,2002 [3].

\begin{tabular}{lcrcrrr}
\hline Country & Total people & \multicolumn{2}{c}{ Male } & \multicolumn{2}{c}{ Female } \\
\cline { 2 - 7 } & $\mathbf{N}$ & $\mathbf{N}$ & $\mathbf{( \% )}$ & $\mathbf{N}$ & $\mathbf{( \% )}$ \\
\hline Morocco & 9,167 & 5,311 & $(57.9)$ & 3,856 & $(42.1)$ \\
Albania & 3,410 & 1,921 & $(56.3)$ & 1,489 & $(43.7$ \\
Philippines & 2,801 & 1,192 & $(42.6)$ & 1,609 & $(57.4)$ \\
Tunisia & 2,624 & 1,772 & $(67.5)$ & 852 & $(32.5)$ \\
China & 2,051 & 1,057 & $(51.5)$ & 994 & $(48.5)$ \\
Pakistan & 1,741 & 1,192 & $(68.5)$ & 549 & $(31.5)$ \\
Serbia-Montenegro & 1,443 & 721 & $(50.0)$ & 722 & $(50.0)$ \\
Bangladesh & 1,366 & 920 & $(67.3)$ & 446 & $(32.7)$ \\
Romania & 1,312 & 577 & $(44.0)$ & 735 & $(56.0)$ \\
Sri Lanka & 958 & 524 & $(54.7)$ & 434 & $(45.3)$ \\
Peru & 483 & 166 & $(34.4)$ & 317 & $(65.6)$ \\
France & 470 & 180 & $(38.3)$ & 290 & $(61.7)$ \\
Senegal & 450 & 353 & $(78.4)$ & 97 & $(21.6)$ \\
Poland & 417 & 86 & $(20.6)$ & 331 & $(79.4)$ \\
Eritrea & 415 & 133 & $(32.0)$ & 282 & $(68.0)$ \\
\hline
\end{tabular}

non-infectious disorders, as specified in hospital discharge diagnoses and "diagnosis-related groups" (DRGs).

All informatized clinical and laboratory charts of our Hospital were retrospectively evaluated, in order to extract information regarding all of the foreign patients admitted as inpatients or followed at Day-Hospital services of all hospital divisions, from January 1, 1999 to March 31, 2004. Both the DRGs related to each admission and the related discharge diagnoses, were carefully examined and compared. Later, we focused our attention on DRGs and medical diagnoses pertaining to infectious diseases. All patients who were followed for a clinical picture, including organ-specific or nonorgan-specific infectious diseases were included in our analysis, regardless of the division(s) of hospital admission.

Statistical data analysis was performed with software in the SPSS 12.0 software package, using the usual indicators of frequency synthesis, and hypothesis testing, including Pearson, the McNemar chi-square test, and the Fisher exact test, with significance established as $\mathrm{p}<0.05$. Graphical elaboration relied on Pareto's diagrams.

\section{Results}

Within a comprehensive pool of 339,051 overall patients, discharged after inpatient admission, 7,311 foreign subjects (representing $2.15 \%$ of total hospitalizations) were selected for in-depth examination: 2,542 (34.8\%) were males, and 4,769 (65.2\%) females. A further 642 Day-Hospital regimen hospitalizations were examined $(0.59 \%$ of overall cases $)$, with a slightly increasing temporal trend between 1999 (0.3\%) and $2002(0.47 \%)$.

The mean age at hospitalization was $36.8 \pm 14.7$ years for adult males and 30.8 \pm 12.0 for adult females (Figure 2). A modal age is clearly recognizable for pediatric patients (aged $\leq 14$ years), and it mostly consists of neonates. While the greatest frequency of hospitalization of adult females is concentrated in the third decade of age (directly linked to fertility and maternity), among adult males the age at admission varies within a significantly broader range (Figure 2 ).

Figure 3 shows the origin of foreign patients according to geographical area and gender; $34.6 \%$ of the hospitalizations were of subjects coming from Eastern Europe, and $15.3 \%$ were from Northern Africa. Western Europe, United States and Canada provided a cumulative total of $7.3 \%$, while the Indian subcontinent contributed 6.9\%, sub-Saharan Africa 5.9\%, and Latin America 5.7\%, followed by San Marino Republic (4.7\%), China (4.1\%), the Philippines (2.5.\%), and the Middle East $(1.1 \%)$. No information was available about the country of origin for about $10.3 \%$ of cases, while $1.1 \%$ of admitted patients had no fixed abode. There was a much higher frequency of women coming from Eastern Europe (significantly prevailing over males, Figure 3 ).

In Table 2 we can see that 7,311 discharge DRGs had 13,441 clinical diagnoses; this phenomenon increases as patient's age increases from neonatal to pediatric to adult (since this latter population is more prone to suffer from multiple disorders). DRGs, although they are good synthetic indicators of the clinical course of diseases, including medical interventions and outcome, are not particularly reliable when an analysis of somewhat unexplored phenomena is carried out, as in the case of hospitalized foreigners and the individualized health care needs of immigrants.

This latter aspect becomes particularly relevant when focusing on infectious diseases as a disease group. In fact, the data reported in Table 3 show that among the 880 DRGs pertaining to infectious disease isolated among the 7,311 DRGs 
Table 2. The frequency of multiple diagnoses and “diagnosis-related group" (DRG) indicators, parallels the increased patients' age at hospitalization, in our survey

\begin{tabular}{|c|c|c|c|c|c|c|c|}
\hline \multirow[b]{2}{*}{ 7,311 DRGs* } & \multicolumn{6}{|c|}{ Number of diagnoses made per each Hospital admission } & \multirow[b]{2}{*}{ Total } \\
\hline & $\begin{array}{c}\text { One } \\
\text { diagnosis }\end{array}$ & $\begin{array}{c}\text { Two } \\
\text { diagnoses }\end{array}$ & $\begin{array}{c}\text { Three } \\
\text { diagnoses }\end{array}$ & $\begin{array}{c}\text { Four } \\
\text { diagnoses }\end{array}$ & $\begin{array}{c}\text { Five } \\
\text { diagnoses }\end{array}$ & $\begin{array}{c}\text { Six } \\
\text { diagnoses }\end{array}$ & \\
\hline \multicolumn{8}{|l|}{ Age } \\
\hline Neonatal & 506 & 81 & 49 & 23 & 5 & 6 & 670 \\
\hline Pediatric & 279 & 233 & 80 & 36 & 10 & 4 & 642 \\
\hline Adult & 2,796 & 1,931 & 723 & 351 & 107 & 84 & 5,994 \\
\hline Total DRGs & 3,581 & 2,245 & 852 & 410 & 122 & 94 & 7,306 \\
\hline Overall diagnoses & 3,581 & 4,490 & 2,556 & 1,640 & 610 & 564 & 13,441 \\
\hline
\end{tabular}

*five cases had incomplete data; in three episodes patient's age is lacking, while in two cases diagnoses were not reported

Table 3. Discrepancies between infectious diseases-related discharges and infectious disease-appropriate diagnosis-related groups (DRGs) at neonatal, pediatric, and adult age, respectively

\begin{tabular}{|c|c|c|c|c|c|c|}
\hline \multirow{2}{*}{$\begin{array}{l}\text { Patient' } \\
\text { age stages }\end{array}$} & \multirow{2}{*}{$\begin{array}{l}7,306 \text { infectious } \\
\text { disease-related or } \\
\text { infectious disease- } \\
\text { unrelated DRGs as } \\
\text { reported in discharge } \\
\text { clinical charts* }\end{array}$} & \multirow{2}{*}{$\begin{array}{l}\text { DRGs selected according to } \\
\text { infectious disease- or } \\
\text { non-infectious disease- } \\
\text { related illnesses }\end{array}$} & \multicolumn{2}{|c|}{$\begin{array}{l}\text { Diagnoses expressed } \\
\text { in the reported } \\
\text { discharge DRGs }\end{array}$} & \multirow{2}{*}{$\begin{array}{c}\mathrm{F}^{2} \\
(\text { chi } \\
\text { square) } \\
\text { value }\end{array}$} & \multirow{2}{*}{$\begin{array}{c}\mathbf{P} \\
\text { value }\end{array}$} \\
\hline & & & $\begin{array}{c}\text { Not } \\
\text { infectious } \\
\text { disease- } \\
\text { related }\end{array}$ & $\begin{array}{c}\text { Infectious } \\
\text { disease- } \\
\text { related }\end{array}$ & & \\
\hline $\begin{array}{l}\text { Neonatal } \\
\text { (age } \leq 1 \text { year) }\end{array}$ & 709 & Non-infectious & 957 & 70 & \multirow{3}{*}{362,901} & \multirow{3}{*}{0.0001} \\
\hline $9.6 \%$ of infectious & \multirow{3}{*}{75} & \multirow{3}{*}{$\begin{array}{l}\text { disease-related } \\
\text { Infectious disease- } \\
\text { related }\end{array}$} & \multirow{3}{*}{62} & \multirow[b]{2}{*}{107} & & \\
\hline $\begin{array}{l}\text { disease-related } \\
\text { DRGs }\end{array}$ & & & & & & \\
\hline Pediatric & & & & & \multirow{3}{*}{147,434} & \multirow{3}{*}{0.0001} \\
\hline $\begin{array}{l}\text { (14 years } \leq \text { age } \\
>1 \text { year })\end{array}$ & 420 & \multirow{2}{*}{$\begin{array}{l}\text { Non-infectious } \\
\text { disease-related } \\
\text { Infectious disease- } \\
\text { related }\end{array}$} & 722 & 61 & & \\
\hline $\begin{array}{l}20.5 \% \text { of infectious } \\
\text { disease-related } \\
\text { DRGs }\end{array}$ & 108 & & 110 & 82 & & \\
\hline Adult & 5,297 & Non-infectious & 9,253 & 604 & \multirow[b]{2}{*}{708,359} & \multirow[b]{2}{*}{0.0001} \\
\hline $\begin{array}{l}11.7 \% \text { of infectious } \\
\text { disease-related } \\
\text { DRGs }\end{array}$ & 697 & $\begin{array}{l}\text { disease-related } \\
\text { Infectious disease } \\
\text { related }\end{array}$ & 1,024 & 391 & & \\
\hline
\end{tabular}

*five cases had incomplete data: in three episodes patient's age is lacking, while in two cases diagnoses were not reported

attributed to foreign patients (representing $12.1 \%$ of total DRGs), the discrepancy between discharge diagnoses (either principal or secondary, and often multiple for each patient) and attributed DRGs indicators, is quite significant at all assessed age classes. There is also frequent disagreement between indicated DRGs and final discharge diagnoses. A relatively high percentage of patients with infectious diseaserelated DRGs have a main diagnosis associated with a broad spectrum of alternative disorders (while the infectious disease was concurrent with or complicated the underlying illness); patients with DRGs other than infectious disease also often suffered from an infectious etiology. This relevant phenomenon that was observed in our series appeared to occur more frequently among adults, when compared with the pediatric population.

Table 4 depicts some discrepancies between infectious disease DRGs and main and secondary clinical diagnoses made upon hospital discharge, analyzed according to body organs and sites, and to motives for hospitalization. Particularly evident discrepancies were found in the gynecologicalobstetrical setting, where infectious disease DRGs seemed to be systematically under-represented $(\mathrm{p}<0.0001$, McNemar chi- 
Figure 1. Foreign population living in Bologna, on December 31,2002 , according to gender distribution [3].

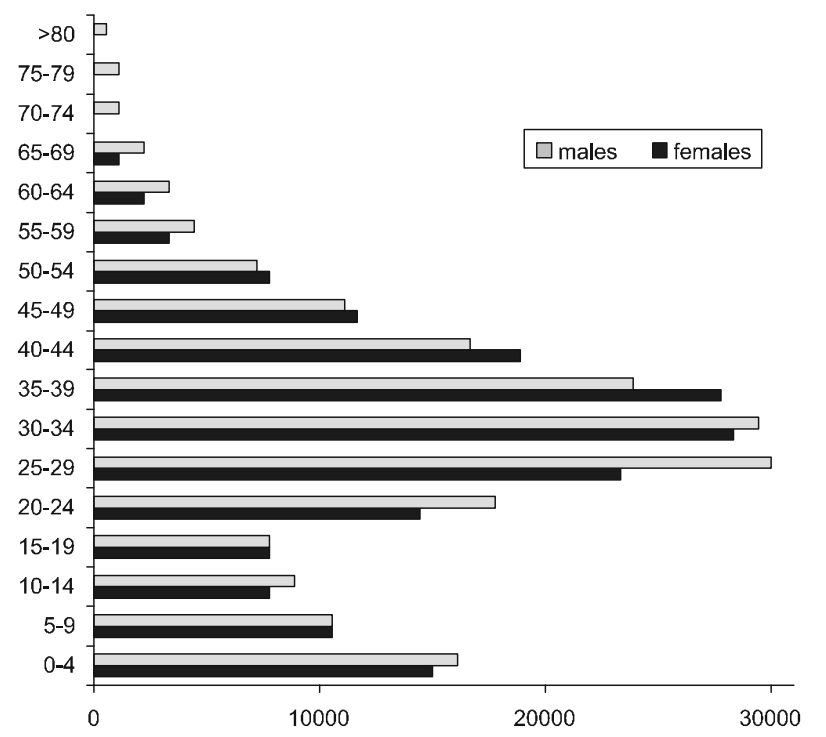

Figure 2. Frequency of hospital admissions of foreign citizens, analyzed according to gender and age classes (age interval considered: one year).

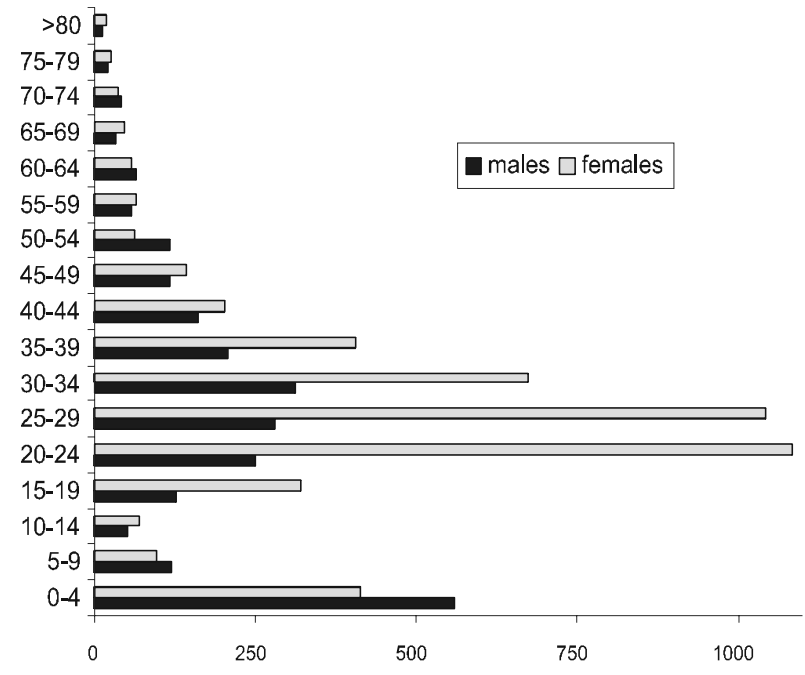

Figure 3. Regions of origin of foreign patients hospitalized at S. Orsola-Malpighi Hospital, presented by geographic area and according to patient's gender.

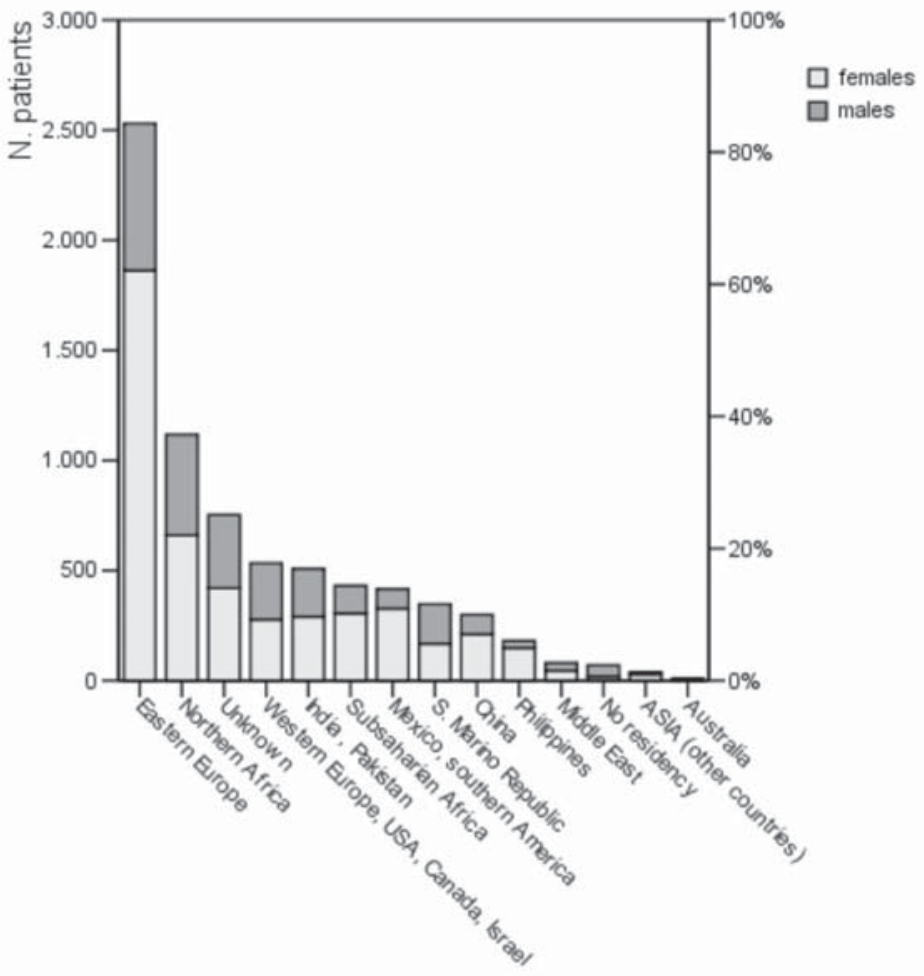

www.bjid.com.br 
square test), followed by gastrointestinal environment $(\mathrm{p}<0.001)$, and ear, nose, and throat $(\mathrm{ENT})$ setting $(\mathrm{p}<0.001)$. The misleading disease classifications found in the fields of respiratory medicine, nephrology and urology, and skin and skin disorders are still important, but not as systematic, compared with the above-mentioned classifications (Table 4). However, significance was reached with the Fisher exact test for all groups of diagnoses reported in Table 4; however, infectious disease DRGs were frequently attributed when main or secondary discharge diagnoses were predominantly psychiatric or related to psycho-social discomfort (32.1\% of cases). Infectious disease DRGs accounted for nearly half (47.1\%) of the discharges after non-organ specific illnesses.

Figures 4 and 5 show the diagnoses at the time of hospital discharge of the foreign patients, and not single quoted DRG indicators.

The causes of hospitalization for adult women are shown in Figure 4; most of them (58.8\%) involved obstetricgynecological procedures, including delivery $(27.1 \%)$ and pregnancy complications $(18.7 \%)$, as well as voluntary pregnancy interruption (4.4\%). Psycho-social problems $(5.4 \%$ of cases), malignancies (5.1\%), and gastroenteric diseases $(4.7 \%)$ were significantly more infrequent, followed by rarer disorders (Figure 4).

Figure 5 depicts the absolute numbers and rates of discharge diagnoses for adult men. The most common motives for hospitalization were traumatic accidents (15.9\% of cases), gastrointestinal disturbances $(12 \%)$, heart and vascular diseases $(8.9 \%)$, psycho-social problems $(8.4 \%)$, lower respiratory tract disease $(7.1 \%)$, nephro-urological diseases (6.1\%), hepato-biliary pathologies (5.2\%), metabolic disorders (4.9\%), and substance or alcohol abuse (4.2\%).

Particular attention should be given to psycho-social disturbances, which include neurosis or psychosis syndromes; they accounted for 137 overall cases among immigrant females, and 95 among foreign men. A proportionally increased frequency of vague and otherwise unspecified diagnoses was found in the patient records, including "nonspecific pain, fever of unknown origin, feeling of abandonment, asthenia, fatigue...", and even "communication troubles" or "lack of domicile", found for 254 women (5.3\%), and 219 men (8.6\% of overall discharge diagnoses).

When considering the overall admissions at our teaching hospital, foreign patients were hospitalized in obstetricgynecological wards in $39.25 \%$ of cases, followed by internal medicine $(13.06 \%)$, surgery (either general or specialist) (7.3\%), specialized medicine services $(7.24 \%)$, pediatrics or neonatology $(7.2 \%)$, and emergency units $(7.12 \%)$. In the remaining $18.82 \%$ of cases, the hospitalization was at other hospital divisions; only 135 patients ( $2 \%$ of the entire population) were admitted as inpatients at our Infectious Diseases unit.

Figure 6 was prepared, based on discharge diagnoses (and not every single DRG indicator); the main observed infectious diseases were recorded from information in the discharge forms of adult subjects. The greatest frequency was of non-organ-specific diseases (23.2\% of women, and $28.4 \%$ of men, respectively), followed by hepatic infections (12.1\% of the men and $24.1 \%$ of the men), obstetricgynecological infections (29.1\% of women), lower respiratory tract illnesses (12.3\% of women, and $19.8 \%$ of men), and nephrological-urological infections $(11.5 \%$ of females and $5 \%$ of males, respectively) (Figure 6).

Detailed analysis of infectious diseases-related diagnoses in children and neonates (Figure 7) demonstrated a comparable prevalence between males and females of nonorgan-specific infectious disorders and ENT infections (26.7\% and $11.1 \%$ for females, compared with $24.4 \%$ and $10.6 \%$ for males, respectively). A higher prevalence of lowerairway infections was found among males $(31.1 \%)$ compared with females $(27.4 \%)$, which was also found for gastrointestinal infections (18.9\% and $14.8 \%$, respectively) (Figure 7).

All illnesses with an infectious etiology are summarized in Table 5, where they are divided according to body organs and sites. Upper respiratory tract infections, pneumonia and lower airways infections, pulmonary tuberculosis, chronic hepatitis, and (with a lower frequency) acute viral hepatitis, acute enterocolitis, acute pyelonephritis, and HIV infection and AIDS, are the main causes of hospital admission due to infectious diseases. Meningitis and encephalitis (considered together) had an appreciable rate of admissions, as did fever of unknown origin and otherwise unspecified septicemia. A negligible frequency of other infectious diseases, which are endemic to specific developing areas located outside of our country, was found; these were definitely rare "imported" infectious disorders.

When we examined the information available on all of the 7,311 foreign patients admitted at S. Orsola Hospital, inpatient hospitalizations had a scheduled discharge in $89.2 \%$ of cases, while patient's voluntary release (against the physician's recommendation) occurred in $8.2 \%$ of cases, and $1.6 \%$ of subjects were transferred to another hospital; the mortality index was only $0.72 \%$. Among voluntary discharges (549 overall cases), $61.7 \%$ of the episodes occurred during the first day of admission, $28.8 \%$ between days 2 and 7, and the remaining cases after 8-36 days of hospitalization.

The duration of admission was very short (1-3 days) in $52.1 \%$ of the cases, while $22.6 \%$ of the patients remained $4-$ 7 days, and $11.2 \%$ of subjects remained 8-14 days. Hospitalization periods longer than 15 days occurred in $24.1 \%$ of cases, while only one patient reached 445 consecutive days since admission. The same analysis, focused on the 130 patients hospitalized at our infectious disease ward, showed that a short duration of hospitalization (1-5 days) occurred in only 16 cases $(12.3 \%)$, while the remaining subjects were hospitalized for from 6 to 114 days. 
Figure 4. Diagnosis at discharge of adult women.

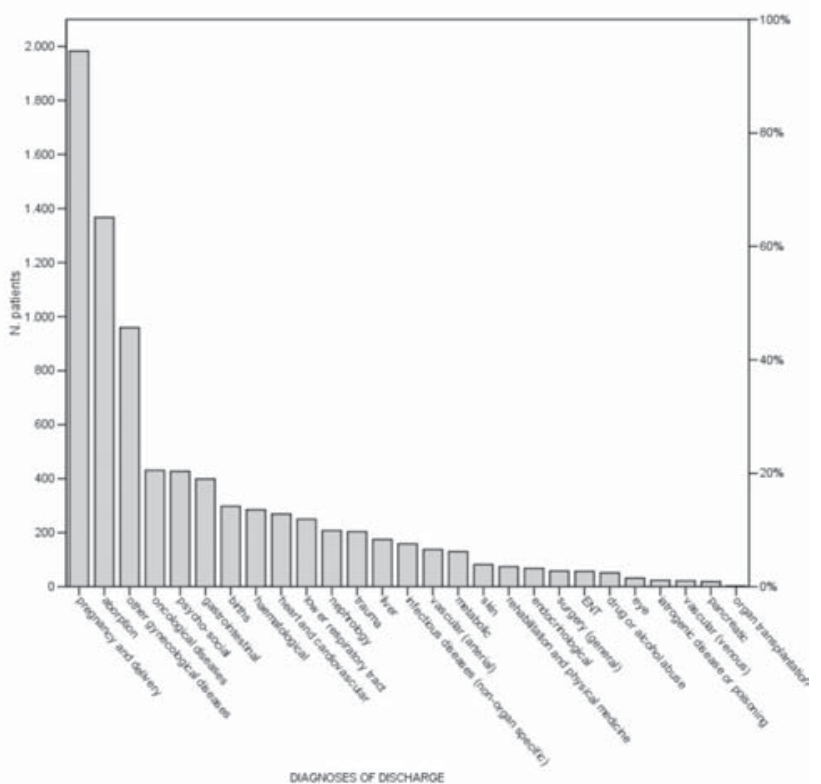

Figure 6. Diagnoses pertaining to infectious diseases, made of adult hospitalized subjects, organized according to patient's gender.

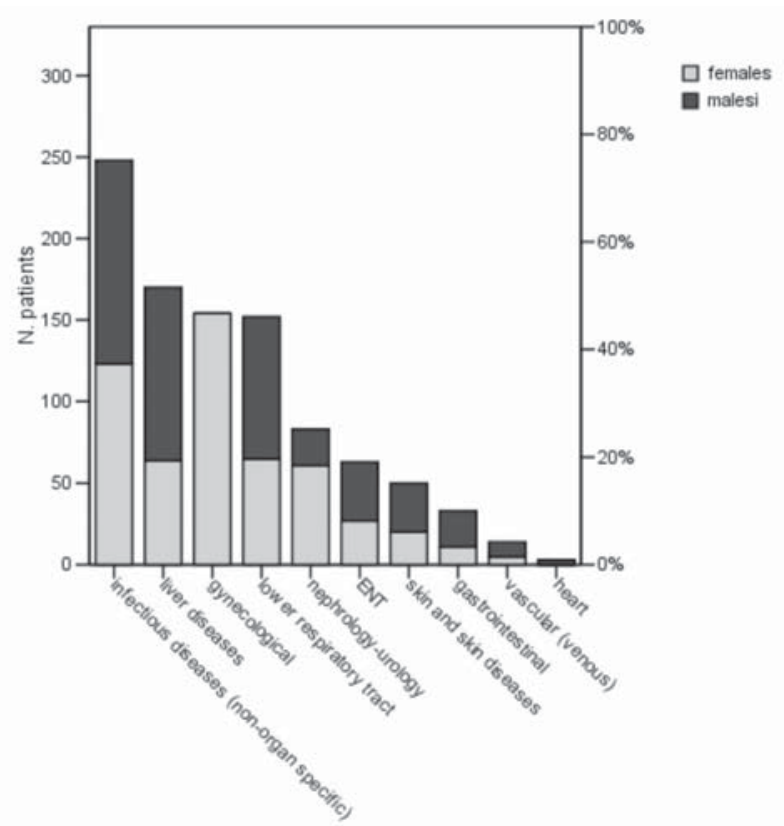

Figure 5. Diagnosis at discharge of adult male patients.

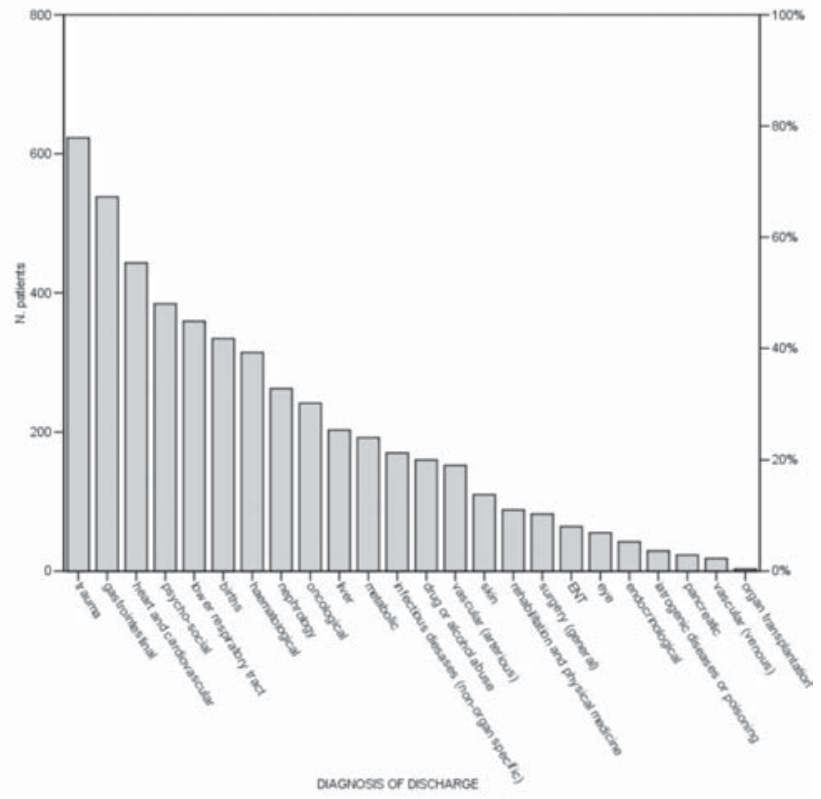

Figure 7. Diagnosis pertaining to infectious diseases among admitted children and neonates (all patients aged less than 14 years).

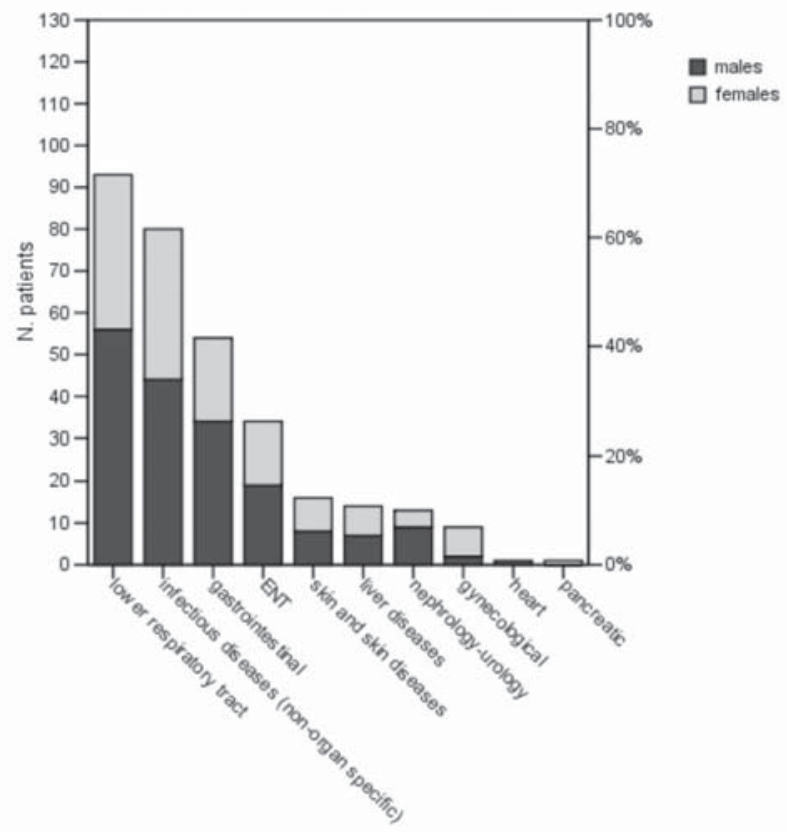


Table 4. Discrepancies between infectious diseases suffered by patients, and reported diagnosis-related group (DRG) indicators, analyzed according to disease site and cause of hospitalization

\begin{tabular}{|c|c|c|c|c|c|}
\hline $\begin{array}{l}\text { Site-organ } \\
\text { pathologies } \\
\text { and causes of } \\
\text { hospitalization }\end{array}$ & Attributed DRGs & $\begin{array}{l}\text { Main and seco } \\
\text { clinical diagn } \\
\text { as reported in } \\
\text { Not infectious- } \\
\text { related }\end{array}$ & $\begin{array}{l}\text { ndary } \\
\text { oses, } \\
\text { clinical charts } \\
\text { Infectious- } \\
\quad \text { related }\end{array}$ & $\begin{array}{l}\text { Fisher } \\
\text { exact test } \\
\text { (p value) }\end{array}$ & $\begin{array}{l}\text { McNemar } \\
\text { chi-square test } \\
\text { (p value) }\end{array}$ \\
\hline $\begin{array}{l}\text { Obstetric- } \\
\text { gynecological }\end{array}$ & $\begin{array}{l}\text { Not infectious } \\
\text { disease-related }\end{array}$ & 791 & 157 & 0.04 & $<0.0001$ \\
\hline diseases & $\begin{array}{l}\text { Infectious } \\
\text { disease-related }\end{array}$ & 10 & 6 & & \\
\hline $\begin{array}{l}\text { Lower } \\
\text { respiratory } \\
\text { tract diseases }\end{array}$ & $\begin{array}{l}\text { Not infectious } \\
\text { disease-related } \\
\text { Infectious disease- } \\
\text { related }\end{array}$ & 252 & 118 & 0.001 & N.S. \\
\hline $\begin{array}{l}\text { Gastrointestinal } \\
\text { diseases }\end{array}$ & $\begin{array}{l}\text { Not infectious } \\
\text { disease-related } \\
\text { Infectious } \\
\text { disease-related }\end{array}$ & $\begin{array}{l}634 \\
216\end{array}$ & $\begin{array}{l}31 \\
56\end{array}$ & 0.001 & $<0.001$ \\
\hline $\begin{array}{l}\text { Nephrological } \\
\text { and urinary tract } \\
\text { diseases }\end{array}$ & $\begin{array}{l}\text { Not infectious } \\
\text { disease-related } \\
\text { Infectious disease- } \\
\text { related }\end{array}$ & $\begin{array}{l}325 \\
49\end{array}$ & $\begin{array}{l}41 \\
55\end{array}$ & 0.001 & N.S. \\
\hline $\begin{array}{l}\text { Skin and skin } \\
\text { tissue diseases }\end{array}$ & $\begin{array}{l}\text { Not infectious } \\
\text { disease-related } \\
\text { Infectious disease } \\
\text {-related }\end{array}$ & $\begin{array}{l}109 \\
17\end{array}$ & $\begin{array}{l}30 \\
36\end{array}$ & 0.001 & N.S. \\
\hline $\begin{array}{l}\text { Ear, nose, and } \\
\text { throat (ENT) } \\
\text { diseases }\end{array}$ & $\begin{array}{l}\text { Not infectious } \\
\text { disease-related } \\
\text { Infectious disease- } \\
\text { related }\end{array}$ & $\begin{array}{l}20 \\
4\end{array}$ & $\begin{array}{l}54 \\
43\end{array}$ & 0.02 & $<0.001$ \\
\hline
\end{tabular}

N.S. = not significant.

\section{Discussion}

Because of its working opportunities and occupational perspectives, and the favorable social and receptive environment, the Bologna metropolitan area located in northeastern Italy is an attractive destination for immigrants, who consequently tend to establish a fixed residence. Data from our area [3] show that the most important foreign communities living in the Bologna area come from Morocco, Albania, and the Philippines (this latter group had the greatest prevalence of females), followed by Tunisia and China (Table 1). Among immigrants into Bologna, younger people largely prevail, including subjects in their working and reproductive years (age class 20-44 years), and children (aged 0-6 years); the latter were mostly born in Italy. The demographic features of this composite population significantly influenced the hospitalization and disease spectrum, which was found to be remarkably different from that of the autochothonous population, which was significantly older, and consequently suffered from a greater prevalence of vascular, degenerative, and oncological illnesses.
Among the foreigners, the male gender was predominant for almost all nationalities (with the greatest incidence of males observed in the Senegalese group: $78 \%$ ). However, in our sample women more frequently resorted to health care structures in their third decade of life (mostly due to fertility and maternity needs). On the other hand, the male gender had a peak of hospitalizations at neonatal age (linked to birth problems), and a proportional, progressive increase in admissions, starting from the second up to the fifth decade of life.

When we examined the different countries of origin of foreign hospitalized patients, we found that proportionally more young females coming from Eastern Europe and Balkans went to the hospital, which is remarkable, especially when we consider the relatively lower numbers of individuals in this group. On the other hand, Northern Africans coming from Morocco and Tunisia, which account for 11,791 regular residents (mostly males), although they are the largest foreign community, they use the hospital much less.

Two particular ethnic groups, the Chinese and the Philippines, present in Bologna for some decades, together 
Table 5. Diseases of strictly infectious disease pertinence, presented according to body sites and organs

\begin{tabular}{|c|c|c|c|}
\hline Body sites and organs & Diagnosed diseases & Further details & No. cases \\
\hline \multirow[t]{3}{*}{ Bone and joints } & \multirow[t]{2}{*}{ Osteomyelitis } & Acute & 4 \\
\hline & & Chronic & 2 \\
\hline & Bone-joint tuberculosis & & 6 \\
\hline \multicolumn{4}{|l|}{ Lower respiratory tract } \\
\hline & Influenza & & 12 \\
\hline & \multirow{3}{*}{ Pneumonia and bronchitis } & Non-specified microbial agents & 212 \\
\hline & & Bacterial & 28 \\
\hline & & Viral & 5 \\
\hline & Pulmonary abscess & & 1 \\
\hline & Pneumocystosis & & 1 \\
\hline & Pleuritis & & 1 \\
\hline & Pulmonary tuberculosis & & 29 \\
\hline \multirow{6}{*}{ Ear, nose, and throat (ENT) } & \multirow{2}{*}{ Otitis media } & Acute & 5 \\
\hline & & Chronic & 2 \\
\hline & Sinusitis & & 2 \\
\hline & Acute rhinopharyngitis & & 95 \\
\hline & Acute tonsillitis & & 13 \\
\hline & Peritonsillar abscess & & 2 \\
\hline \multirow{2}{*}{\multicolumn{4}{|c|}{$\begin{array}{l}\text { Gastrointestinal } \\
\text { Tract }\end{array}$}} \\
\hline & & & \\
\hline & \multirow[t]{3}{*}{ Acute hepatitis } & Hepatitis A virus & 1 \\
\hline & & Hepatitis B virus & 11 \\
\hline & & Hepatitis $\mathrm{C}$ virus & 5 \\
\hline & Chronic hepatitis & & 44 \\
\hline & Liver abscess & & 1 \\
\hline & Liver echinococcosis & & 3 \\
\hline & Pancreatitis & & 1 \\
\hline & Parotitis & & 2 \\
\hline & Gastrointestinal & Esophagitis & 1 \\
\hline & tract infections & Non-specified enterocolitis & 28 \\
\hline & & Salmonellosis & 1 \\
\hline & & Campylobacteriosis & 2 \\
\hline & & Clostridium difficile infection & 1 \\
\hline & & Adenovirus infection & 1 \\
\hline & & Rotavirus infection & 3 \\
\hline & & Non-specified parasite infection & 2 \\
\hline \multirow[t]{4}{*}{ Kidney and urinary tract } & \multirow[t]{2}{*}{ Pyelonephritis } & Acute & 7 \\
\hline & & Chronic & 21 \\
\hline & Cystitis & & 7 \\
\hline & Non-specified infection & & 15 \\
\hline \multirow[t]{3}{*}{ Genital tract } & \multirow[t]{2}{*}{ Female patients } & Obstetric infections & 69 \\
\hline & & Gynecological infections & 94 \\
\hline & Male patients & & 4 \\
\hline \multirow[t]{8}{*}{ Skin and skin tissues } & \multirow{8}{*}{$\begin{array}{l}\text { Skin and } \\
\text { subcutaneous tissues }\end{array}$} & & \\
\hline & & Finger abscess & 1 \\
\hline & & Erysipela & 13 \\
\hline & & Herpes zoster & 4 \\
\hline & & Impetigo & 1 \\
\hline & & Pyodermitis & 1 \\
\hline & & Viral exanthems & 3 \\
\hline & & Filariasis & 1 \\
\hline
\end{tabular}




\begin{tabular}{|c|c|c|c|}
\hline Body sites and organs & Diagnosed diseases & Further details & No. case \\
\hline & Orbitary cellulitis & & 2 \\
\hline \multirow{5}{*}{$\begin{array}{l}\text { Central and peripheral } \\
\text { nervous system }\end{array}$} & Meningitis & Tubercular & 1 \\
\hline & & Bacterial & 3 \\
\hline & & Viral & 7 \\
\hline & Encephalitis & & 2 \\
\hline & Non-specified neuritis & & 17 \\
\hline \multirow[t]{10}{*}{ Non-organ specific diseases } & Malaria & & 6 \\
\hline & Syphilis & Congenital & 1 \\
\hline & & Acquired & 5 \\
\hline & HIV disease & HIV infection & 30 \\
\hline & & Full-blown AIDS & 2 \\
\hline & & Symptomatic HIV infection & 6 \\
\hline & Infectious mononucleosis & & 5 \\
\hline & Lyme disease (borreliosis) & & 1 \\
\hline & Ancylostomiasis & & 1 \\
\hline & Leishmaniasis & & 1 \\
\hline \multicolumn{4}{|l|}{ Concurrent } \\
\hline \multirow[t]{4}{*}{ Diseases } & Bacterial superinfection & & 3 \\
\hline & Post-surgical infections & General, surgical infections & 1 \\
\hline & & Post-transplantation diseases & 5 \\
\hline & Septicemia & & 12 \\
\hline \multicolumn{3}{|l|}{$\begin{array}{l}\text { Fever of } \\
\text { unknown origin }\end{array}$} & 26 \\
\hline \multicolumn{3}{|l|}{ Total } & 768 \\
\hline \multirow{2}{*}{\multicolumn{3}{|c|}{$\begin{array}{l}\text { Other infectious disease disorders which did not require specialistic intervention or consultancy } \\
\text { Total number of diseases etiologically attributable to infectious agents (theoretical overall number } \\
\text { of infectious diseases that occurred in our hospital setting }\end{array}$}} & 379 \\
\hline & & & 1,147 \\
\hline
\end{tabular}

accounted for 4,852 residents, thus representing the third and the fifth communities, though they used hospital health care resources relatively little, limited to around $8 \%$ of these inhabitants. These data are not surprising, since Chinese citizens usually prefer to resort to their traditional medicine network, which has been well established in Bologna for many years. People coming from the Philippines are in a different situation, as they have more elevated instruction levels, and are exposed to more favorable working and environmental conditions (the majority of this subgroup consists of women working as housekeepers).

Foreign citizens coming from India and surrounding regions, sub-Saharan Africa, and Latin America, although they are a minority (with partial exceptions for those coming from Pakistan and Bangladesh), they have a proportionally greater rate of hospitalization. This may be the result of seeking for temporary solutions to social, economic, and existential inconveniences of recently immigrating populations, which do not find favorable responses in the community setting.

Hospitalization of Western citizens is proportionally frequent in overall number, but only France is found among the first 15 ethnic communities (470 individuals, Table 1); the French accounted for around $7 \%$ of admissions. Most of these hospitalizations involved non-residents, who during their temporary stay in Bologna resort to emergency services and hospitals, as they lack first-line (outpatient) local medical aid. The non-negligible number of citizens of the S. Marino Republic probably seeks hospitalization in Bologna for a broad range of diseases, even though they can use their national health care system, customized for around 28,000 inhabitants.

In our comprehensive analysis of a five-year series of hospitalized people, around $10 \%$ of foreigners were of unknown origin; this is probably due to clandestinity, as they normally would only have access to health care through emergency and hospital-mediated procedures.

When the distribution of discharge diagnoses was analyzed, a significant difference was found according to patient gender. Among women, obstetric-gynecological causes were largely predominant, while psycho-social, oncological, and gastroenteric disturbances were of lesser concern. On the other hand, traumatic events prevailed among males, followed by gastroenteric, heart and vascular, psychosocial, and lower respiratory tract diseases. As a consequence, overall admissions at our hospital predominantly involved obstetrical-gynecological problems ( $40 \%$ of cases), while internal medicine, surgery, medical specialties, pediatricsneonatology, and our infectious diseases unit accounted for a minority of hospital visits. 
The detailed analysis of DRG indicators related to the hospitalization of foreign citizens confirmed that these parameters are not suitable for epidemiological studies [4,5], although DRGs have been favorably used in oncology in France [6], and for heart disorders in the United States [7], where they were used in well-defined, autochtonous populations, with specific diagnostic features. In fact, typical infectious disease diagnoses are frequently recorded in association with other non-specific disorders, so that DRG indicators are not appropriately defined in the field of infectious diseases, and vice versa. In most of the adult patients of our survey, the final discharge diagnoses were the consequence of multiple, associated illnesses, some of them infectious in origin, which may (or may not) have been included among quoted infectious disease DRGs.

In our experience, only a limited percentage of hospitalized foreign citizens $(12.1 \%)$ suffer from primary (predominant) infectious disease-related illnesses, as recorded in the discharge forms. This percentage was similar to the figures reported from other regions of Italy [2]. Among infectious disorders, an important role of HIV infection [8-13], viral hepatitis [2,8,14], sexually-transmitted diseases [15], and malaria [2,16,17], was also found in our study. Given that many adult patients with infectious diseases had multiple discharge diagnoses and multiple DRGs, and that infectious disorders could co-exist with non-infectious ones, misclassifications and discrepancies between the actual infectious diseases presented by the patients and their DRG scores, may be particularly evident for lower airway, gynecological, and ENT infections, as well as non-organspecific infectious diseases. On the other hand, when infectious disease DRGs were recorded and analyzed, psychiatric comorbidity and psycho-social discomfort also proved to be frequent concomitant conditions, demonstrating the importance of social distress for foreign immigrants. All these data and related indications could be extremely useful in order to correct the relative "weight" of infectious diseases among inpatients admitted to the hospital, emphasizing subjects with frequent comorbidity and relevant diagnostic-therapeutic engagement (and related, relevant expenses).

Among foreign adults followed at our hospital, non-organ specific diagnoses proved to be the most frequent among infectious diseases discharge diagnoses, followed by pulmonary, liver, and obstetric-gynecological disorders, observed with decreasing frequency. Among foreign children, the most frequent infectious disease diagnoses involved respiratory problems, followed by non-organ specific illnesses in both males and females, as well as gastrointestinal infections (as also observed in a recent local survey) [18].

When considering the outcomes of foreign patient hospitalizations, these ended with a regular discharge in the great majority of cases, while in a minority of episodes transfer to another health care center was deemed necessary. An appreciable percentage of foreigners opted for an anticipated, voluntary discharge; it is possible that a broad spectrum of factors (language and cultural difficulties, obligations due to the hospital regimen, other environmental and familial conditions, dietary changes, absence of religious and psychological support, limited admission of visitors and relatives, and existential solitude) played a significant role in this phenomenon. The extremely low mortality rate of hospitalized foreigners $(0.72 \%)$ was essentially connected with the low mean age of immigrants, and the low rate of degenerative and oncological illnesses.

On the whole, over $60 \%$ of admissions of foreign citizens lasted 1-7 days, and therefore were proportionally short in duration; two-thirds of this group remained in the hospital for only 1-3 days. This latter figure is largely influenced by obstetrical admissions, due to non-complicated deliveries. An "intermediate" duration of hospitalization (8 to 14 days) accounted for a limited $11.2 \%$ of cases, while proportionally longer admissions were caused by multiple problems, including almost always psychosocial discomfort. Among infectious disease DRGs related to patients hospitalized in our division or in other hospital units, a significant percentage of discharge diagnoses involved psychiatric, psycho-social, and toxicological causes, therefore confirming older observations about autochtonous, HIV- or chronic-hepatitis-infected patients [19-21].

\section{Conclusions}

Our in-depth analysis of all hospitalizations of foreign patients during the last five years in the main teaching hospital of Bologna, Italy (S. Orsola-Malpighi General Hospital) allows us to make some conclusions about trends, even though limitations are expected from such a retrospective study design, essentially based on data coming from electronic databases of demographic, clinical, and outcome features of evaluated subjects, which often includes "mismatches" between discharge diagnoses and attributed DRGs.

Our study population predominantly included proportionally young subjects, with numerous admissions associated with delivery and other obstetric-gynecological problems (such as voluntary pregnancy interruption). The male subjects had a significantly lower tendency towards hospitalization, and this was particularly true for northern Africans. A predominant involvement of psycho-social disturbances was found. While their occurrence may precede immigration, most of these problems are usually triggered or exacerbated by a large number of inconveniences directly or indirectly related to the migratory process, and often may condition or complicate underlying organic diseases. Traumatic causes predominate among men; however, nonorgan specific infectious disorders, and respiratory tract, liver, and gastrointestinal infections proved to be proportionally frequent in this foreign citizen population.

Since immigrants are predominantly young and otherwise healthy, hospitalizations tend to be short in duration, and not infrequently end with voluntary discharge (as a possible 
expression of personal or environmental discomfort, reduced compliance to both hospital environment and rules, and/or the lack of a cultural concept of prolonged disease). Based on these data, in the near future we should be concerned about a worrying increase of young-people illnesses (including drug and alcohol abuse), among the children of immigrants born in Italy, due to predominant psycho-social determinants that have become important in some minorities. The history of the HIV pandemic and that of hepatotropic viruses (HBV and $\mathrm{HCV}$ ) led to a rapid spread of these communicable, infectious diseases through drug use, and also resulted in people having diffuse psycho-social discomfort [10,19-21]. Given the present epidemiological trend, traumatic illnesses might also increase in frequency, considering the possible supporting role of alcohol or drug use among temporary male workers or those relying on a temporary job.

It has become very necessary to develop an increased awareness of these varied realities, which would allow a significantly increased level of attention towards different atrisk situations, beginning with the availability of dedicated social-health care territorial structures, the implementation of consulting services specifically devoted to foreign and immigrant citizens, and outpatient health care centers that could precociously reveal emerging discomforts and minor health care problems, giving immediate aid to patients, and concurrently avoiding the need to use hospital centers and emergency services. Finally, Medicine now needs to encompass a sort of "anthropological" knowledge and attitude, still underrated in our technical and cultural continued educational programs, which could help in interpreting the needs of foreign, non-Western people [22]. It is quite probable that a fully open and empathic approach would allow a more rapid and effective integration of foreign citizens into our present society, as well as a more appropriate use of hospital health care resources and correct planning of future economic and professional allocations.

\section{Acknowledgements}

The authors thank Dr. Corrado Moschettini, Servizio Informativo Aziendale, Azienda Ospedaliera di Bologna, Policlinico S. Orsola-Malpighi, Bologna, Italy, for his assistance.

\section{References}

1. Caritas Italiana, Rome. Migrantes. Dossier statistico immigrazione 2003. XIII rapporto sull'immigrazione. Available online at: www.caritasitaliana.it/immigrazione, 2003.

2. Carosi G., Capone S., Matteelli A. Impatto delle grandi endemie (TBC, AIDS, Malaria) sulla patologia infettiva del migrante in Italia. Giornale Italiano di Malattie Infettive 2004; 10(Suppl1):570-3.

3. Lelleri R., Gentile E. Immigrati in Provincia di Bologna: i numeri e le tendenze. Osservatorio delle Immigrazioni n. 2, 2003. Also available at: www.provincia.bologna.it/immigrazione, 2003.
4. Goodpasture H., Nguyen-Dang C.T., Lee T.H., et al. Miscoding as cause of elevated simple pneumonia mortality. It Comm J Qual Saf 2004;30:335-41.

5. Di Lenarda A., Goliani P., Grella M., et al. Hospital statistics as tool in epidemiologic studies: hearts failure in Trieste. Ital Heart J 2002 (Suppl.);3:58-70.

6. Paviot B.T., Martin C., Clavel L., et al. From DRG data-bases to an epidemiological observatory for colorectal cancer in a French small area oncology network. Stud Health Technol Inform 2003;95:829-33.

7. Kiyota Y., Schneeweiss S., Glynn R.J., et al. Accuracy of medicare claims-based diagnosis of acute myocardial infarction: estimating positive predictive value on the basis of review of hospitals records. Am Heart J 2004;148:99-104.

8. Sabbatani S., Cannella B., Zanna S. Dati clinico-epidemiologici su una casistica di pazienti extracomunitari di Bologna ricoverati per patologie infettive. Giornale Italiano di Medicina Tropicale 2000;5:57-65.

9. Vincent A., Moneta S., De Gennaro M., et al. Patologia infettiva in pazienti extracomunitari con infezione da HIV. Proceedings of the XIV Congresso Nazionale AIDS e Sindromi Correlate, Milan (Italy), November 2000:62.

10. Manfredi R., Calza L., Chiodo F. HIV disease among immigrants coming to Italy from outside of the European Union: a casecontrol study of epidemiological and clinical features. Epidemiol Infect 2001; 127:527-33.

11. Scolari C., El-Hamad I., Matteelli S., et al. Incidence of tuberculosis in a community of Senegalese immigrants in Northern Italy. Int J Tubercle Lung Dis 1999;3:18-22.

12. Sabbatani S., Manfredi R., Legnani G., Chiodo F. Tuberculosis in a metropolitan area of northern Italy: epidemiological trends and public health concerns. Eur J Epidemiol 2004;19:501-3.

13. Santoro D., Visonà R., Pusterla L., Vigevani G.M. Immigrant admissions to hospital: a retrospective study in Como from 1994 to 1998. J Travel Med 2000;7:300-3.

14. Gabutti G., Fedele A., Aprile V., et al. Immigration flows and new epidemiological evidence in southern Italy. Vaccine 2003;21:399-400.

15. Giuliani M., Suligoi B. Italian STI Surveillance Working Group. Differences between nonnational and indigenous patients with sexually transmitted infections in Italy and insight into the control of sexually transmitted infections. Sex Transm Dis 2004;31:79-84.

16. Castelli F., Matteelli A., Caligaris S., et al. Malaria in migrants. Parassitologia 1999,41:261-5.

17. Scolari C., Teodoldi S., Casalini C. Knowledge, attitude and practice on malaria preventive measures of migrants attending a public health clinic in Northem Italy. J Travel Med 2002:9:160-162.

18. Stampi S., Matteini P., Zanetti F., Baldi E. Immigration and health: observational study concerning the foreign children attending the Bologna Community pediatric service. Ann Ig 2003; 15 :261-70.

19. Galli M., Musicco M. Mortality of intravenous drugs users living in Milan, Italy: role of HIV-1 infection, AIDS 1994;8:1457-63.

20. Sabbatani S., Tuminelli P., Giorgi L., et al. Analisi dei ricoveri di utenti di un SERT di Bologna con diagnosi di dimissione ospedaliera di tipo psichiatrico. Epidemiologia per la Salute 1995; 15:63-9.

21. Goedert J.J., Pizza G., Gritti F.M., et al., Mortality among drug users in the AIDS era. Int J Epidemiol 1995;24:1204-10.

22. Caprara A. Similitudine e contiguità. Elementi di antropologia del contagio. Rivista Italiana di Sociologia e Antropologia Medica 1996;2:89-109. 